\title{
PENGEMBANGAN MODEL PEMBELAJARAN MOTORIK DENGAN MODIFIKASI PERMAINAN TRADISIONAL UNTUK SEKOLAH DASAR KELAS ATAS
}

\section{DEVELOPING A MOTOR LEARNING MODEL THROUGH MODIFIED TRADITIONAL GAMES FOR UPPER GRADE STUDENTS OF ELEMENTARY SCHOOL}

\author{
Hasbi, Pamuji Sukoco \\ SD Cakra Mataram Nusa Tenggara Barat, Universitas Negeri Yogyakarta \\ Bi_hasbi@rocketmail.com, psukoco@yahoo.co.id
}

\begin{abstract}
Abstrak
Penelitian ini bertujuan untuk menghasilkan model pembelajaran motorik dengan menggunakan modifikasi permainan tradisional untuk anak sekolah dasar kelas atas yang baik, efektif dan menyenangkan yang dapat digunakan oleh guru pendidikan jasmani. Penelitian ini merupakan penelitian pengembangan (education research and development $(R \& D)$ yang mengadaptasi penelitian pengembangan menurut Borg \& Gall (1983, p.775) yaitu: (1) potensi dan masalah; (2) pengumpulan informasi; (3) desain produk (draf model); (4) validasi ahli dan revisi; (5) uji coba lapangan skala kecil dan revisi; (6) uji coba lapangan skala besar dan revisi; (7) pembuatan produk final, revisi uji coba skala kecil pada 27 siswa kelas IV di SD Negeri Catur Tuggal Sleman; (8) uji coba produk skala besar pada 40 siswa kelas IV dan kelas V SD Kanisius Baciro, Sleman; (9) revisi produk dan, (10) deseminasi dan implementasi pengembangan model pembelajaran. Instrumen yaitu: (1) wawancara; (2) skala nilai; (3) observasi guru; (4) observasi keefektifan model, dan (5) kuesioner siswa. Teknik analisis data yaitu analisis deskriptif kualitatif dan kuantitatif. Hasil penelitian ini berupa model pembelajaran motorik dengan modifikasi permainan tradisional berisikan lima permainan yaitu: (a) gobak sodor; (b) bola kasti; (c) jemprak/engklek; (d) lompat kubur, dan (e) kucing-tikus, dan bentuk buku panduan. Hasil menunjukkan bahwa model pembelajaran motorik dengan modifikasi permainan tradisional untuk sekolah dasar kelas atas direspon baik dan efektif. Hal ini dibuktikan dengan persentase pada setiap data kuantitatif di atas $70 \%$ pada skala besar. Respon peserta didik menghasilkan respon positif dan dapat digunakan dalam pembelajaran.
\end{abstract}

Kata Kunci: model pembelajaran motorik, modifikasi bermain, tradisional.

\begin{abstract}
This study aims to produce a good, effective and fun motor learning model using modified traditional games for upper grade students of elementary school which can be used by elementary physical education teachers. This research was an education research and development $(R \& D)$ study adapted the steps of Borg \& Gall (1983, p.775) research development including: (1) the potency and problems; (2) the collection of information; (3) a draft models of product design; (4) design validation; (5) the trial test of small scale design revision; (6) large-scale field trials and revisions; (7) the final product making, the small-scale revision on the 27 upper grade students, consisted of fourth grade students of State Elementary School at Catur Tuggal Sleman; (8) the large-scale product trials conducted on the 40 upper grades students of fourth and fifth grade of Elementary School Canisius Baciro, Sleman; (9) product revision, (10) development dissemination and implementation. The data collection instruments used were: (1) interview; (2) the value scale; (3) teacher's observation; (4) the observation of model effectiveness, and (5) questionnaires for students. The data analysis technique used was qualitative and quantitative descriptive analysis. The result is a model of motoric learning through modified traditional games for upper grades students of elementary school which contain five games namely: (a) the game of gobak sodor; (b) a kasti ball; (c) jemprak/hopscotch; (d) lompat kubur, and (e) cat and mouse, which are arranged in the form of guide books. Based on the data analyzed from experts' assessment and students' questionnaires, it could be concluded that the learning motoric model through modified traditional games for the upper grades students of elementary school is good and effective. This is evidenced by the quantitative data percentage above $70 \%$ on a large scale. The response of the research's subject is the positive response and can be used for teaching.
\end{abstract}

Keywords: motoric learning model, modified game, traditional. 


\section{Pendahuluan}

Usaha mengembangkan potensi keterampilan motorik dan perkembangan anak sekolah dasar kelas atas secara menyeluruh membutuhkan layanan latihan atau berupa pendekatan permainan untuk memperbaiki motorik kasar dengan penanganan sesuai karakteristik dan kemampuan anak sekolah dasar kelas atas.

Model pembelajaran merupakan suatu cara atau strategi yang dilakukan oleh seorang guru agar terjadi proses belajar pada diri siswa untuk mencapai suatu tujuan yang dirancang secara sistematis. Menurut Sudjana (Sugihartono, dkk, 2007, p.74) menyatakan model pembelajaran merupakan setiap upaya yang dilakukan dengan sengaja oleh pendidik yang dapat menyebabkan peserta didik melakukan kegiatan belajar. Menurut Gagne (Wena, 2009, p.10) pembelajaran yang efektif harus dilakukan dengan berbagai cara dan menggunakan berbagai macam media pembelajaran.

Penentuan model pembelajaran yang akan digunakan dalam kegiatan pembelajaran harus mempertimbangkan: (a) tujuan yang hendak dicapai, (b) bahan atau materi pembelajaran, (c) peserta didik, dan (d) pertimbangan lainnya yang bersifat nonteknis (Rusman, 2011, p.133).

Model pembelajaran yang akan dikembangkan ini adalah model pembelajaran motorik dengan modifikasi permainan tradisional untuk meningkatkan motorik kasar anak sekolah dasar kelas atas yang akan dikembangkan disesuaikan dengan Kompetensi Inti (KI) dan Kompetensi Dasar (KD) Kurikulum 2013 tahun 2013 mata pelajaran pendidikan jasmani untuk sekolah dasar kelas atas, khususnya kelas 4 dan 5 .

Pembelajaran motorik dapat diartikan sebagai suatu proses belajar yang mengarah pada dimensi gerak. Rahyubi (2012, p.209) menyatakan bahwa pembelajaran motorik adalah suatu upaya mengubah perilaku motorik melalui kondisi dan situasi yang sengaja diciptakan agar proses perubahan menjadi efektif dan efesien. Menurut Oxendine (Nugroho, 2005 , p.9) kemampuan motorik adalah terminolagi yang digunakan untuk menggambarkan kecakapan seseorang dalam berbagai keterampilan yang agak mengarah penguasaan keterampilan dasar dan aktifitas kesegaran yang bersifat umum.

Fungsi motorik menurut Cureton (Mutohir dan Gusril, 2004, p.51). menyatakan fungsi utama kemampuan motorik adalah untuk mengembangkan kesanggupan dan kemampuan setiap individu yang berguna untuk mempertinggi daya kerja. Dengan mempunyai kemampuan motorik yang baik, tentu individu mempunyai landasan untuk menguasai tugas keterampilan motorik yang khusus. Semua unsurunsur motorik pada setiap anak dapat berkembang melalui kegiatan olahraga dan aktivitas bermain yang melibatkan otot. Semakin banyak anak mengalami gerak tentu unsur-unsur kemampuan motorik semakin terlatih dengan banyaknya pengalaman motorik yang dilakukan tentu akan menambah kematangannya dalam melakukan aktivitas motorik. Secara umum tujuan pembelajaran motorik adalah agar anak memiliki keterampilan gerak yang memadai, sekaligus mengambangkan aspek kognitif, aspek fisik, dan aspek afektif/sosial.

Menurut Irianto (2002, p.3) menyatakan bahwa kebugaran jasmani dapat dikelompokkan menjadi tiga yaitu: (a) kebugaran statistik, (b) kebugaran dinamis, (c) kebugaran motoris. Sujiono (2007, pp.3-6) mengemukakan bahwa unsur-unsur kesegaran jasmani meliputi kekuatan, daya tahan, kecepatan, kelincahan, kelenturan, koordinasi, ketepatan dan keseimbangan. Lebih lanjut Sujiono (2007, p.13) menyatakan bahwa gerakan yang timbul dan terjadi pada motorik kasar merupakan gerakan yang terjadi dan melibatkan otot-otot besar dari bagian tubuh, dan memerlukan tenaga yang cukup besar.

Menurut Arlina (2008, p.10) permainan tradisional anak adalah proses melakukan kegiatan yang menyenangkan hati anak dengan mempergunakan alat sederhana sesuai dengan keadaan dan merupakan hasil penggalian budaya setempat menurut gagasan dan ajaran turuntemurun dari nenek moyang.

Menurut Ardiwinata (2006, p.1) olahraga tradisional merupakan kebudayaan nenek moyang bangsa Indonesia. Olahraga tradisional harus memenuhi dua persyaratan yaitu berupa "olahraga" dan sekaligus juga "tradisional" baik dalam memiliki tradisi yang telah berkembang selama beberapa generasi, maupun dalam arti sesuatu yang terkait dengan tradisi budaya suatu bangsa secara lebih luas. Berat ringannya teknik dari berbagai bentuk olahraga tradisional di Indonesia sangat bervariasi. Persyaratan teknik yang ada dalam olahraga tradisional diantaranya adalah kekuatan tubuh, kelentukan, kecepatan gerak, kemampuan reaksi. Nilai-nilai budaya yang terkandung di 
dalamnya bentuk olahraga tradisional adalah penghargaan pada usaha yang keras untuk mencapai prestasi unggul, penghargaan pada prestasi orang lain, pesaing, ikatan kelompok religiusitas dan lain-lain. Olahraga tradisional perlu dikembangkan atau di modifikasi demi ketahanan budaya bangsa, karena harus disadari bahwa kebudayaan merupakan nilai-nilai luhur bagi bangsa Indonesia. Selain itu olahraga tradisional merupakan salah satu aspek yang perlu mendapatkan prioritas utama untuk dilestarikan, dilindungi, dibina, dikembangkan, diberdayakan yang selanjutnya diwarisi agar tidak hilang oleh perkembangan jaman atau hilang diambil oleh Negara lain. Dengan demikian maksud olahraga tradisional dalam penelitian ini adalah serangkaian aktivitas fisik untuk anak sekolah dasar (SD) kelas atas yang terencana dan teratur dengan menggunakan model pembelajaran permainan tradisional yang memiliki tujuan untuk mengembangkan motorik kasar anak sekolah dasar (SD) kelas atas. Olahraga tradisional yang akan digunakan dalam penelitian ini adalah model pembelajaran modifikasi permainan tradisional sodor, kasti, engklek, lompat kubur dan permainan tradisional kucing-tikus untuk anak sekolah dasar kelas atas.

Singer (Sukadiyanto, 2012, p.1) menyatakan bahwa pengalaman dan praktek intensif dalam berbagai keterampilan motorik akan menghasilkan kemudahan dalam penguasaan keterampilan. Oleh karena itu, pada masa kecilnya anak memiliki berbagai pengalaman pola gerak dasar dan berbagai aktivitas, akan lebih mudah melakukan berbagai keterampilan motorik. Dengan demikian keterampilan gerak dasar (motorik kasar dan halus) dalam bentuk gerak lokomotor, non-lokomotor dan manipulatif yang diberikan pada anak sekolah dasar akan menjadi dasar dalam pembelajaran motorik yang baru atau menuju kepada kualitas keterampilan jasmani pada tingkat selanjutnya.

Berdasarkan hasil observasi awal terhadap aktivitas guru dan siswa dalam pelajaran Penjaskes di SDN 6 Catur Tunggal dan SD Kanisius Baciro, Sleman, Yogyakarta, ditemukan beberapa masalah yang dihadapi baik oleh guru maupun oleh siswa di kedua sekolah tersebut dalam hal pembelajaran motorik. Masalah pertama yang dihadapi para guru Penjas SD dalam pelaksanaan pembelajaran motorik yaitu kurangnya pemahaman dan kreativitas guru dalam menyusun model pembelajaran motorik yang variatif dan menarik sehingga anak tidak bosan. Kurangnya pemahaman dan kreativitas guru Penjas ini berpengaruh terhadap cara guru mengajar di lapangan yang masih bersifat konvensional dan minim pembaharuan di dalam pembelajaran. Hal ini terlihat dalam pembelajaran motorik pendidikan jasmani di sekolah. Dalam pembelajaran tersebut, guru memberikan materi praktek gerak dasar yang sama setiap semester tanpa adanya pengembangan variasi gerak atau modifikasi sehingga bersifat monoton.

Masalah kedua yang dihadapi guru Penjaskes SD dalam pelaksanaan pembelajaran motorik yaitu kurangnya sarana dan prasarana yang dapat mendukung proses pembelajaran motorik dalam pendidikan jasmani. Kurangnya sarana dan prasarana merupakan permasalahan klasik yang dihadapi oleh sekolah. Kondisi seperti ini menyebabkan kurangnya kreatifitas guru dalam menyiapkan sarana pembelajaran (modifikasi peralatan olahraga) yang sesuai dengan tuntutan kurikulum secara mudah dan praktis guna mengatasi keterbatasan ketersediaan sarana dan prasarana olahraga di sekolah. Kurangnya kreatifitas guru olahraga dalam menyiapkan sarana pembelajaran dapat dilihat dari kegiatan pengajaran guru yang hanya memberikan praktek yang tersedia alatnya saja, sedangkan materi praktek yang lainnya tidak diberikan karena alat yang dibutuhkan tidak ada atau rusak.

Masalah ketiga yang dihadapi guru Penjaskes SD dalam pelaksanaan pembelajaran motorik yaitu jumlah jam pelajaran yang terbatas untuk memberikan materi pembelajaran motorik yang memerlukan waktu lama dalam proses belajarnya. Jumlah jam pelajaran dikatakan terbatas karena alokasi waktu pelajaran Penjaskes di sekolah dasar hanya seminggu sekali (3 x 35 menit). Hal ini mengakibatkan kurangnya waktu/kesempatan siswa untuk melakukan latihan suatu keterampilan gerak siswa yang tidak maksimal. Praktek pembelajaran motorik adalah kegiatan yang memberikan kesempatan sebanyak-banyaknya bagi siswa untuk melakukan gerakan/praktek. Dengan demikian dalam pelaksanaan proses pembelajaran di sekolah belum dapat mencapai hasil yang maksimal, karena berbagai permasalahan dan kendala yang dihadapi oleh sekolah maupun guru.

Berdasarkan permasalahan tersebut maka peneliti ingin mencoba untuk melakukan penelitian pengembangan dengan topik masalah "Pengembangan model pembelajaran motorik dengan modifikasi permainan tradisional untuk 
meningkatkan motorik kasar anak sekolah dasar kelas atas"'.

\section{Metode}

\section{Jenis Penelitian}

Penelitian ini merupakan penelitian pengembangan (education research and development $(R \& D)$. Sukmadinata $(2011$, p.164) menyatakan bahwa penelitian pengembangan adalah suatu proses atau langkah-langkah untuk mengembangkan suatu produk baru atau menyempurnakan produk yang telah ada, yang dapat dipertanggungjawabkan.

Prosedur Pengembangan

Langkah-langkah tersebut diadaptasi menjadi (7) rancangan prosedur penelitian pengembangan yaitu (1) pengembangan informasi di lapangan, (2) analisis informasi, (3) mengembangkan produk awal (Draf Model), (4) validasi ahli dan revisi, (5) uji coba lapangan skala kecil dan revisi, (6) uji coba lapangan skala besar dan revisi dan (7) pembuatan produk final.

\section{Uji Coba Produk dan Data Penelitian}

Uji coba produk/draft model dilakukan sebanyak 2 kali yaitu uji coba skala kecil dan uji coba skala besar. Uji coba produk skala kecil dilakukan terhadap siswa kelas IV Catur Tuggal 6 Sleman, Yogyakarta yang berjumlah 24 anak, sementara uji coba skala besar dilakukan terhadap siswa kelas IV dan V yang berjumlah 40 siswa.

Jenis data yang diperoleh dalam penelitian dan pengembangan ini yaitu data kualitatif dan data kuantitatif. Data kualitatif berasal dari (a) hasil wawancara dengan guru pendidikan jasmani SD, (b) data kekurangan model permainan dari ahli materi dan guru yang melakukan uji coba permainan, dan (c) data masukan ahli materi dan guru pelaku uji coba terhadap model permainan. Data kuantitatif diperoleh dari (penilain ahli materi terhadap permainan), (d) penilain ahli materi terhadap guru pelaku uji coba.

Pengumpulan data dilakukan dengan wawancara, observasi, dan skala nilai dengan menyusun kategori. Kategori yang dimaksud dalam skala penilitian ini adalah kategori berskala dua, yaitu sesuai dan tidak sesuai. Cara penggunaan skala penilaian yaitu, bilamana muncul gejala atau unsur-unsur seperti yang terdapat dalam klarifikasi data, para pakar dan guru memberikan tanda cek (v) pada kolom kategori yang sesuai (Nawali \& Hadari (2006, pp.79-81) apabila gejala atau unsur-unsur seperti yang terdapat dalam klarifikasi data ditanyakan sesuai maka nilainya satu (1), apabila ditanyakan tidak sesuai maka nilainya nol (0).

Teknik Analisis Data

Data kuantitatif untuk menghitung kuantitas data dengan analisis, terlebih dahulu menentukan persentase dari hasil observasi dengan rumus menurut Sudijono, (2011, pp.4041) sebagai berikut

Keterangan:

$$
\mathrm{P}=\frac{\mathrm{F}}{\mathrm{N}} \times 100 \%
$$

\section{P: Persentase skor aktifitas yang diperoleh}

F: skor aktifitas yang diperoleh berdasarkan deskriptor

$\mathrm{N}$ : skor maksimal.

Data kualitatif yang terdiri dari: (1) data hasil wawancara dengan guru SD saat studi pendahuluan, (2) data kekurangan dan masukan terhadap model permainan baik sebelum uji coba maupun setelah uji coba, diperoleh langsung melalui analisis deskripsi masing-masing masukan, dan kekurangan terhadap model permainan ini.

\section{Indikator Keberhasilan}

Data Kuantitatif indikator keberhasilan yang dijadikan alat ukur dalam penelitian dan pengembangan model pembelajaran ini adalah, apabila persentase hasil data yang bersifat kuantitatif berupa: (1) data skala nilai hasil penelitian para ahli materi terhadap draft model permainan sebelum pelaksanan uji coba di lapangan, (2) data hasil observasi para ahli materi terhadap model permainan, (3) data hasil observasi para ahli materi terhadap permainan, (4) hasil observasi para ahli materi terhadap guru pelaku uji coba, adalah sama atau di atas $70 \%$, maka dapat dikatakan bahwa model pembelajaran motorik dengan modifikasi pendekatan permainan tradisional dapat mengembangkan atau memperbaiki aspek motorik kasar pada peserta didik. Sedangkan indikator keberhasilan data kuantitatif untuk mengukur kinerja anak saat melakukan model permainan (aktifitas siswa) adalah sama atau lebih dari nilai 70 untuk 
masing-masing aspek yang dinilai dalam tiap permainan.

Data kualitatif, pengembangan model pembelajaran motorik dengan modifikasi pendekatan permainan tradisional ini dikatakan berhasil dengan melihat langsung deskripsi dari: (1) data hasil wawancara dengan guru SD saat studi pendahuluan, (2) data kekurangan dan masukan terhadap model permainan baik sebelum uji coba maupun setelah uji coba.

\section{Hasil Penelitian dan Pembahasan}

\section{Pelaksanaan Permainan Gobag Sodor}

Tujuan pembelajaran (1) mengembangkan kesadaran tubuh, kesadaran ruang dan arah (ranah motor), (2) mengembangkan kemampuan motorik kasar kecepatan, kelincahan, melempar, dan menangkap dan (3) melatih kerja sama dan bersosial dalam bermain sodor (indikator ranah efektif). Peralatan: gobak sodor (kapur, bola plastik, pita dan peluit)

Peraturan permainan dalam permainan Selodor adalah guru membuat lapangan gobak sodor, selanjutnya guru mengukur panjang dan lebarnya lapangan $17 \mathrm{~m}$ x $9 \mathrm{~m}$, menjadi 16 bagian (lapangan selodor di sesuaikan dengan jumlah siswa) dalam satu petak/kotak ukurannya 4 meter jarak dengan kotak yang lain, bentuk aktivitas dapat dilihat pada gambar 1 , dan 2 berikut.
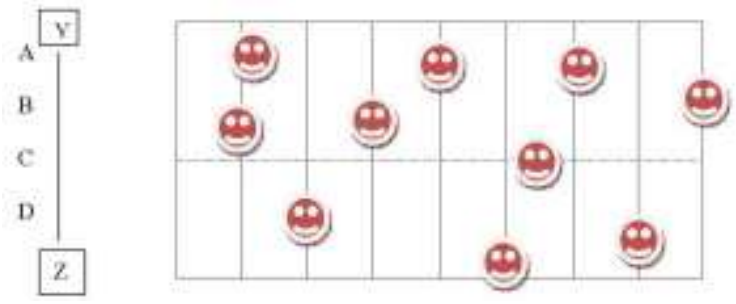

Gambar 1. Bentuk Lapangan Gobak Sodor.

Pemain terdiri dari 2 regu masing-masing kelompok terdiri dari 10 orang. Sebelum permainan dimulai diadakan undian, yang kalah sebagai tim penjaga dan yang menang sebagai tim penyerang dengan diberikan tanda ikat fungsinya untuk membedakan mana tim penyerang dengan tim penjaga. Regu penjaga menempati garisnya masing-masing dengan kedua atau salah satu kaki berada di atas garis sodor, sedangkan regu penyerang siap untuk masuk menerobos hadangan. Permainan dimulai setelah wasit membunyikan peluit. Penyerang berusaha mengoper bola ke temannya saat salah satu temannya sudah masuk ke petak kedua melewati garis depan atau tingkatan dengan meng- hindari tangkapan bola atau sentuhan penjaga. Penjaga berusaha menangkap bola dan menyentuh penyerang dengan tangan dalam posisi kedua kaki atau salah satu kaki berpijak pada garis sodor, sedangkan kaki yang satu lagi melayang. Apabila dalam mengoper bola dapat ditangkap penjaga sebanyak dua (3) kali atau tersentuh pemainnya sebanyak dua (3) kali, maka tim penyerang dikatakan mati, dan tim penyerang berganti menjadi tim penjaga. Apabila bola keluar dari arena permainan/garis sodor sebanyak dua (3) kali, maka tim penyerang dikatakan mati dan berganti posisi menjadi tim penjaga. Setelah tim penyerang sampai pada tahap akhir, tanpa sentuhan maka penyerang berbalik arah dan melakukan permainan seperti permainan biasa, lihat gambar 2 berikut ini.

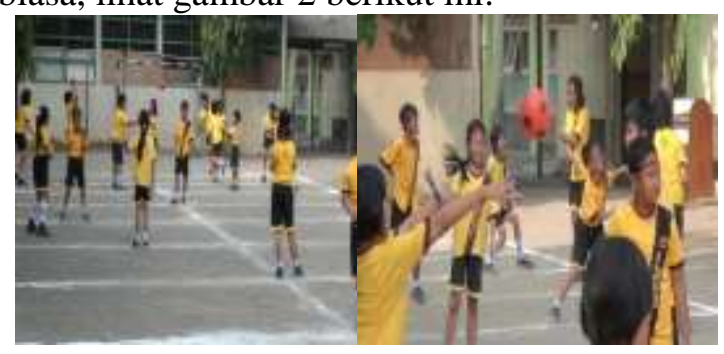

Gambar 2. Pelaksanaan permainan gobak sodor.

Setiap kelompok berusaha untuk melakukan permainan dengan sempurna (bentuk kompetisi yang bersifat rekreatif). Peserta didik harus berusaha menerobos di setiap garis sodor dan berusaha untuk menghindari sentuhan dari tim penjaga garis, serta tim penyerang berusaha untuk menangkap bola agar tidak ditangkap oleh penjaga garis sodor, setelah tim penyerang sudah mencapai finis maka tim penyerang berusaha untuk masuk ke petak sodor berbalik arah dan berusaha untuk menyelesaikan permainan dengan melewati tim penjaga sodor sampai selesai. Terlihat dari gambar peserta didik semakin bersemangat dalam melakukan aktivitas permainan sodor.

\section{Pelaksanaan Permainan Bola Kasti}

Tujuan Pembelajaran (1) mengembangkan kesadaran tubuh, kesadaran ruang dan arah (ranah motor), (2) memahami berbagai variasi gerakan lari, (3) kelincahan, dan menangkap (indikator ranah kognitif), (4) mengembangkan kemampuan motorik kasar, kecepatan, kelincahan, memukul, melempar, dan menangkap dan (5) mengembangkan sikap kerja sama, kejujuran dan sportif (indikator ranah afektif). Peralatan: kayu pemukul, tiang (base), bola tenis dan peluit. 
Peraturan peralatan dan bentuk aktivitas dalam permainan bola kasti. Modifikasi Permainan Kasti lihat gambar 3 dan 4 berikut ini.

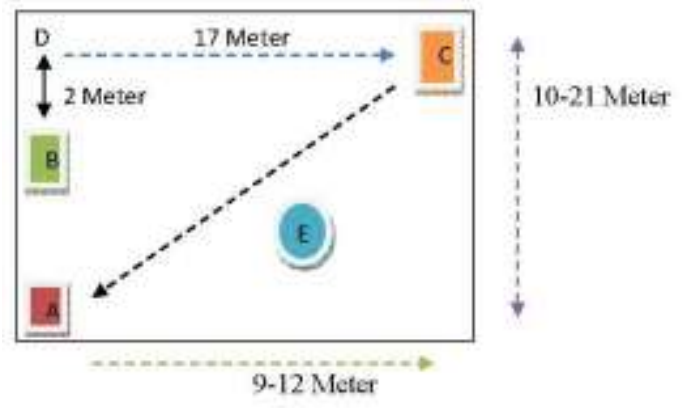

Gambar. 3 Lapangan Bola Kasti

Keterangan:

- - - - - - J Jalur lari pemain dari base

A. Ruang bebas/ruang tunggu

B. Tempat memukul bola

C. Base/pemberhentian

D. Tempat penjaga belakang

E. Kotak bom

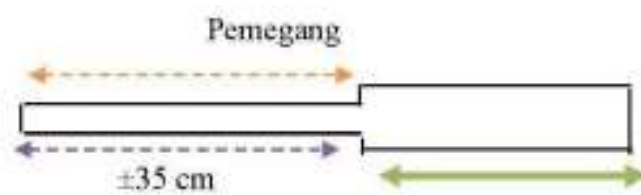

$\pm 25 \mathrm{~cm}$

Gambar 4. Alat Permainan Bola Kasti.

Partai pemukul masuk ke ruang pemukul, dan melakukan dribel bola kasti ke bawah beberapa kali, lalu melambungkan bola sendiri dan memulai untuk memukul. Bila pukulan tidak kena atau salah pemain berhenti di situ, menunggu pukulan betul dari pemain lain, untuk lari ke ruang hinggap. Bila pukulannya betul pemain lari ke ruang hinggap, tetapi bila pemain takut, pemain boleh kembali ke ruang pemukul untuk menunggu kesempatan yang baik. Pemain dari partai lapangan berusaha untuk menangkap bola dan mencoba melempar bola ke kotak bom yang sudah disediakan untuk mematikan lawan jika "kotak bom" kena lemparan.

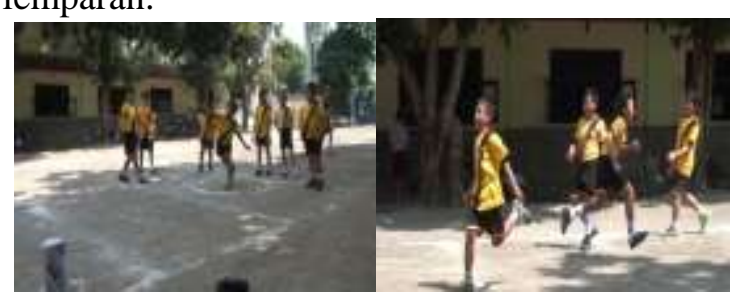

Gambar 5. Pelaksanaan Permainan Bola Kasti

\section{Pelaksanaan Permainan Engklek/Jemprek}

Tujuan pembelajaran mengembangkan kesadaran tubuh, kesadaran ruang dan arah (ranah motorik) adalah meningkatkan kemampuan motorik kasar, lompat, loncat, lempar, dan menendang dan mengembangkan sikap kejujuran, toleransi, dan kerja sama (indikator ranah afektif). Peralatan: lapangan, kapur dan bola plastik. Pengaturan cara bermain dan bentuk aktivitas seperti pada gambar berikut ini.

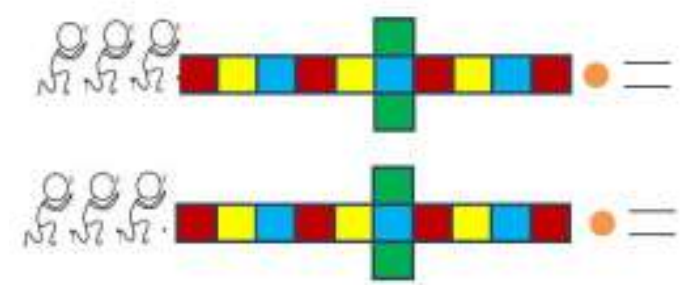

Gambar 6. Bentuk Lapangan Jemprak/Engklek

Keterangan Gambar 6 sebagai berikut: (1) Bentuk lapangan Engklek berbentuk petak/ kotak yang berukuran panjang 6 meter lebar kotak ukurannya setengah meter, dibagi menjadi 12 kotak dan dua petak berada di samping kiri dan kanan sehingga membentuk persegi empat dempet vertical dan (2) di akhir kotak/depan kotak/petak ditaruh bola plastik dengan jarak dari petak $30 \mathrm{~cm}$ dan di depan bola dibuat menyerupai sebuah gawang bola sebagai sasaran untuk menendang, jarak bola dengan sasaran menendang berjarak 1 meter, lebar sasaran 1 meter.

Siswa dibariskan bershaf ke belakang sebelum melakukan lompatan terhadap area lapangan permainan. Siswa melakukan jingkatan dengan posisi kaki terangkat dan melalui setiap petak/kotak setelah sampai ke petak akhir maka posisi kaki kanan siswa tetap dalam keadaan di angkat dengan berusaha menendang bola memakai kaki kanan dan berusaha menendang bola serta berusaha memasukan bola ke sasaran yang sudah disediakan. Jika siswa sudah menggunakan jingkatan dengan memakai kaki kanan, maka siswa tersebut mengulangi lagi dengan menggunakan kaki kiri untuk jingkatan. Jika siswa dapat memasukkan bola ke sasaran maka mendapatkan 1 poin. Jika siswa tidak bisa memasukkan bola ke sasaran maka siswa tersebut tidak mendapatkan poin, lihat gambar 7 berikut ini. 


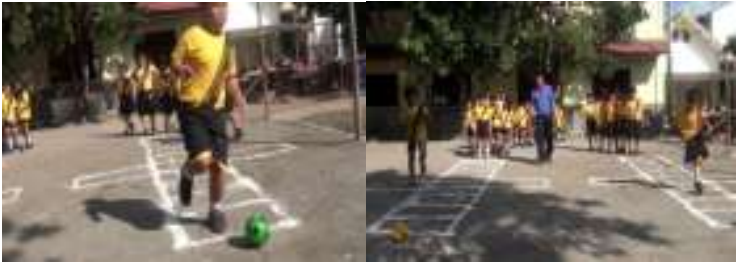

Gambar 7. Pelaksanaan Permainan Jemprak/Engklek.

Pelaksanaan Permainan Lompat Kubur

Tujuan pembelajaran adalah (1) mengembangkan kesadaran tubuh, kesadaran ruang dan arah (ranah motor), (2) meningkatkan gerak lari,kecepatan, lompat, jengket, kelincahan dan koordinasi (indikator ranah motorik), (3) mengembangkan kemampuan gerak lokomotor dan non-lokomotor (indikator motorik), (4) dapat bekerja sama dalam melaksanakan tugas kelompok (indikator ranah efektif) dan (5) memahami konsentrasi (indikator ranah kognitif). Peralatan lapangan, dan peluit. Pengaturan bentuk aktivitas sebagai berikut.
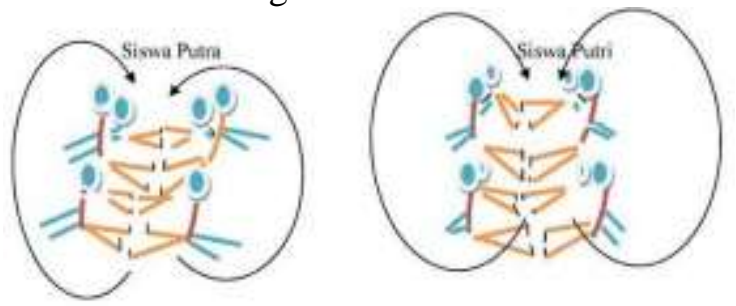

Gambar 8. Lompat Kubur

Siswa dibariskan dengan posisi duduk bersilang dengan temannya dalam posisi duduk kaki diluruskan. Posisi kaki siswa saling bertemu membentuk sebuah kotak-kotak kecil, siswa disuruh berhitung setiap satu pasangan untuk menentukan nomor dan posisi duduknya. Guru memberikan aba-aba siap, lalu guru memanggil nomor yang dipanggil setelah dipanggil guru membunyikan pluit siswa segera untuk bergerak dan melewati setiap kaki-kaki temannya yang sedang duduk. Siswa berusaha untuk melewati setiap kaki temannya dengan melompat setelah berhasil sampai barisan akhir temannya, lalu siswa berbelok arah di luar barisan temannya sambil berlari dan melakukan lompatan setiap kaki temannya menuju tempat duduk. Siswa lainya menunggu giliran untuk dipanggil serta bersiap-siap mendengar guru memangggil nomor yang dipanggil dan guru membunyikan peluit dan seterusnya, lihat gambar 9 berikut ini.

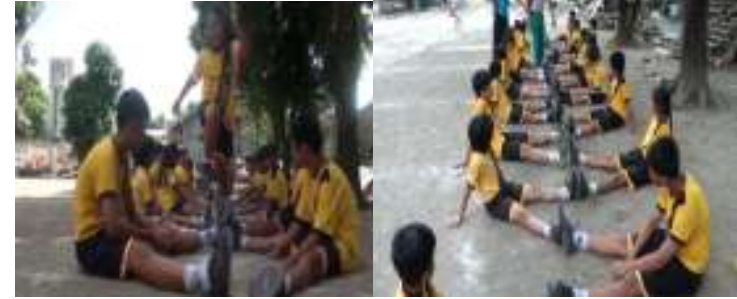

Gambar 9. Pelaksanaan Permainan Lompat Kubur

\section{Pelaksanaan Permainan Kucing Tikus}

Tujuan pembelajaran (1) mengembangkan kesadaran tubuh, kesadaran ruang dan arah (ranah motorik), (2) Memahami konsentrasi (indikator ranah kognitif), (3) mengembangkan kemampuan gerak lokomotor (indikator motorik), (4) meningkatkan kemampuan motorik kasar, kelincahan, dan kecepatan (indikator ranah motorik), dan (5) dapat bekerja sama dalam melaksanakan tugas kelompok (indikator ranah afektif). Peralatan dalam permainan ini tidak menggunakan peralatan hanya menggunakan halaman atau tempat yang kosong.

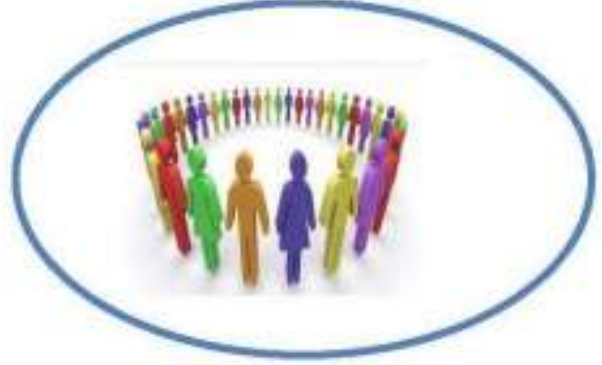

Gambar 10. Lapangan Bermain Kucing-Tikus

Guru menentukan/memberikan ikat berupa pita setiap siswa agar mudah ditunjuk siapa yang dikejar. Semua siswa disuruh berhitung untuk menentukan nomor urut masing-masing siswa. Guru menunjukkan dua siswa yang mengejar dan yang dikejar, misalnya yang ditunjuk nomor 2 dan nomor 5 jadi nomor 2 berusaha menyentuh atau menangkap nomor 5 siswa yang saling mengejar tidak boleh keluar dari arena yang sudah dibuat oleh guru. Jikalau nomor 5 bisa disentuh atau ditangkap oleh nomor 2 maka hukuman untuk nomor 5 menggendong nomor 2 dan guru melanjutkan permainan dengan aturan yang sama, lihat gambar 11 berikut ini.

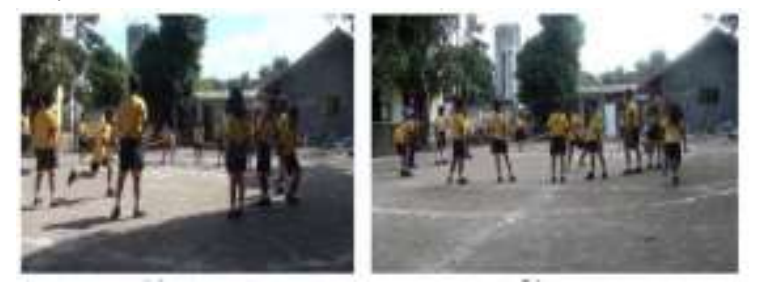

Gambar 11. Pelaksanaan Permainan Kucing Tikus 
Data Masukan dari Ahli Materi

Masukan-masukan terhadap permainan dipaparkan pada tabel sebagai berikut.

Tabel 1. Masukan Model Pembelajaran Permainan Modifikasi Tradisional Gobag Sodor

\begin{tabular}{cl}
\hline Ahli Materi & $\begin{array}{l}\text { Masukan Permainan Modifikasi } \\
\text { Tradisional Gobag Sodor }\end{array}$ \\
\hline Guru SD & $\begin{array}{l}\text { Alokasi waktu permainan tidak } \\
\text { cukup. }\end{array}$ \\
Prn) & - Lapangan permainan sodor \\
& ditambah menjadi dua lapangan \\
& agar semua siswa aktif bergerak \\
& dalam pembelajaran. \\
& - Dalam permainan bola kasti \\
& kotak bom terlalu dekat. \\
- Dalam permainan gobak sodor \\
diberi tanda berupa pita. \\
Pakar 2 (Shj) \\
Dalam permainan gobak sodor \\
bola plastik diganti lebih kecil. \\
Pengkondisian siswa harus \\
diperhatikan.
\end{tabular}

Tabel 2. Masukan Model Pembelajaran Permainan Modifikasi Tradisional Engklek

\begin{tabular}{cl}
\hline Ahli Materi & \multicolumn{1}{c}{$\begin{array}{c}\text { Masukan Terhadap Model } \\
\text { Permainan Engklek/Jemprak }\end{array}$} \\
\hline Guru SD (Krn) & - \\
Pakar 1 (Skd) & - \\
Pakar 2 (Shj) & $\begin{array}{l}\text { Dalam permainan jemprak siswa } \\
\text { harus bergantian kaki kiri dan kaki } \\
\text { kanan. }\end{array}$ \\
\hline
\end{tabular}

Tabel 3. Masukan Model Pembelajaran Permainan Modifikasi Tradisional Lompat Kubur

\begin{tabular}{clc}
\hline \multirow{2}{*}{ Ahli Materi } & \multicolumn{3}{c}{ Masukan terhadap Model } \\
& \multicolumn{4}{c}{ Permainan Lompat Kubur } \\
\hline Guru SD (Krn) & \multicolumn{3}{c}{} \\
Pakar 1 (Skd) & $\begin{array}{l}\text { Dalam } \\
\text { semua }\end{array}$ & sermainan lompat kubur \\
& $\begin{array}{l}\text { sepatu, serta posis memaki duduknya } \\
\text { bersilang satu dengan teman }\end{array}$ \\
lainnya. & \\
Pakar 2 (Shj) & & -. \\
\hline
\end{tabular}

Tabel 4. Masukan Model Pembelajaran Permainan Modifikasi Tradisional Kucing Tikus

\begin{aligned} & \hline Ahli Materi \multicolumn{2}{c}{ Masukan terhadap Model } \\ & Permainan Lompat Kubur \\ & \hline Guru SD (Krn) \\ & Pakar 1 (Skd) $\begin{array}{l}\text { Dalam permainan kucing-tikus } \\ \text { dibuat zona lingkaran sebagai } \\ \text { pembatas } \\ \text { Dalam permainan kucing-tikus } \\ \text { siswa diberi pita sebagi tanda untuk } \\ \text { membedakan kucing dengan tikus }\end{array} \\ &$\hline\end{aligned}

Analisis Data Masukan dari Ahli Materi

Analisis data permainan Gobak Sodor terdapat beberapa masukan dari ahli materi terhadap model permainan. Masukan pertama dari ahli yaitu bahwa dalam permainan Gobak Selodor lapangan ditambah menjadi dua lapangan sehingga semua siswa ikut bergerak aktif. Dari masukan tersebut, peneliti selanjutnya melakukan revisi terhadap draf model dengan membuat dua lapangan Gobak Selodor. Oleh karena itu, lapangan permainan dibuat menjadi dua lapangan agar semua siswa bisa bergerak aktif dalam pembelajaran.

Masukan kedua dari ahli materi yaitu dalam permainan Gobak Sodor tim regu pemain diberikan tanda untuk membedakan pemain dengan penjaga, serta pemakian alat dari bola plastik yang dipakai diganti dengan bola plastik yang lebih kecil. Peneliti selanjutnya melakukan revisi terhadap draf model dengan membuat/memberikan penjelasan dengan alat yang dipakai dalam proses pembelajaran dengan mengantikan bola plastik yang lebih kecil dalam permainan gobak sodor.

Analisis data dalam permainan Jemprak/Engklek terdapat beberapa masukan dari ahli materi pertama yaitu, dalam permainan Jemprak/Engklek petak/kotak jingatan ditambah petaknya menjadi 12 petak/kotak. Peneliti selanjutnya melakukan revisi terhadap draf model dengan menyesuaian dengan keadaan lapangan sekolah. Dari masukan ahli materi ini peneliti mencoba untuk menambah kotak dalam permainan Jemprak/Engklek. Masukan dari ahli kedua terdapat masukan yaitu dalam permainan Jemprak/Engklek setiap siswa menggantikan kaki kiri dan kaki kanan saat melakukan jingkatan sehingga siswa bisa menghasilkan tumpuan kaki yang seimbang. Peneliti selanjutnya melakukan revisi dari masukan ini peneliti mencoba untuk menambah petak/kotak jemprak sehingga siswa tidak terlalu lama dalam mendapatkan giliran.

Analisis data permainan lompat kubur terdapat beberapa masukan dari ahli materi pertama yaitu, dalam permainan lompat kubur semua siswa disuruh untuk memakai sepatu untuk menjaga kemungkinan cidera/kena serta posisi duduk siswa bersilang dan aturan keselamatan diutamakan. Oleh karena itu peneliti selanjutnya melakukan revisi terhadap draf model permainan agar dalam permainan lompat kubur semua siswa memakai sepatu, merubah posisi 
duduk siswa serta mengutamakan keselamatan siswa.

Analisis data permainan kucing-tikus terdapat beberapa masukan dari ahli materi dalam model modifikasi permainan kucing-tikus masukan pertama dari ahli materi yaitu, sebelum melakukan permainan kucing-tikus sebaiknya membuat zona pembatas. Dari masukan tersebut, selanjutnya peneliti melakukan revisi terhadap model permainan untuk membuat batasan sebagai batas tempat kucing-tikus berlari saling kejar-kejaran.

Masukan kedua dari ahli materi yaitu dalam permainan kucing-tikus diberikan tanda untuk membedakan mana yang menjadi kucing dan mana yang menjadi tikus. Oleh karena itu peneliti selanjutnya melakukan revisi terhadap draf model permainan untuk menyiapkan tanda berupa pita sebagai pembeda dalam permainan modifkasi permainan tradisional kucing-tikus.

\section{Analisis Data Validasi Ahli}

Hasil penilaian skala nilai yang diberikan pakar/ahli materi terhadap revisi draf awal model sebelum diuji cobakan di lapangan, para ahli materi: (1) Prof. Dr. Sukadiyanto, M. Pd (bidang ahli permainan), (2) Prof. Dr. Suharjana (Bidang ahli pembelajaran pendidikan jasmani) dan 2 Guru Penjaskes sekolah dasar sependapat bahwa model pembelajaran permainan dengan modifikasi permainan tradisional yang terdiri dari 5 permainan, yaitu: (a) permainan selodor, (b) permainan bola kasti, (c) permainan engklek/jemprak, (d) permainan lompat kubur, dan (e) permainan kucing-tikus, yang dimodifikasi dinilai telah sesuai, dengan adanya itemitem atau hasil-hasil observasi penilaian skala nilai dinyatakan layak untuk diujicobakan di lapangan.

\section{Analisis Data Uji Coba Skala Kecil}

Uji coba skala kecil dilakukan di SD Negeri Catur Tunggal 6 Yogyakarta, dengan sampel siswa kelas atas yaitu kelas IV yang terdiri dari 27 siswa.

Dari penilaian ahli materi terdapat instrumen observasi pada uji coba skala kecil, para ahli materi sependapat bahwa model pembelajaran permainan tradisional yang terdiri dari 5 macam modifikasi permainan, yaitu: (a) permainan gobak sodor, (b) permainan bola kasti, (c) permainan engklek/jemprak, (d) permainan lompat kubur, dan (e) permainan kucing-tikus, yang dikembangkan termasuk dalam kategori baik dan efektif.
Walaupun model sudah memenuhi item-item observasi, namun terdapat beberapa masukan dari para ahlimateri yaitu: (1) permainan selodor lapangan ditambah sehingga semua siswa ikut bergerak dalam pembelajaran permainan tradisional, (2) pada permainan lompat kubur pengelolaan siswa/kelas harus lebih baik lagi. Menyikapi masukan dari para ahli materi terdapat model yang dimodifikasi, peneliti selanjutnya melakukan perbaikan untuk penyempurnakan produk lebih lanjut sebelum melakukan uji coba skala besar.

Analisis data kuesioner untuk guru uji coba menunjukkan bahwa hasil data observasi untuk guru pelaku uji coba di lapangan menunjukkan bahwa dalam menerapkan model-model permainan yang sudah di rancang pelaku uji coba terlihat efektif dalam pemakaian terhadap peserta didik.

Analisis data kuesioner siswa menunjukkan bahwa hasil data kuesioner untuk siswa menujukkan bahwa respon dari peserta didik yang menjadi sampel pada uji coba skala kecil, secara umum memberikan respon yang positif terhadap model pembelajaran dengan modifikasi permainan tradisional terdapat $(18,5 \%)$ yang menyatakan mengalami kelelahan dalam mengikuti pembelajaran dengan model yang dimodifikasi, hal ini dikenakan kondisi tingkat kebugaran siswa yang tidak sama serta karakteristik siswa sekolah dasar masih berada pada usia tumbuh kembang.

\section{Analisis Uji Coba Skala Besar}

Uji coba skala besar dilakukan di SD Kanisius Baciro Yogyakarta, dengan sampel siswa terdiri dari dua kelas atas yaitu: kelas IV dan kelas $\mathrm{V}$, dengan jumlah sampel siswa terdiri dari 40 siswa sekolah dasar kelas atas.

Analisis data uji coba skala besar menunjukkan bahwa dari penilaian ahli materi terdapat instrumen observasi pada uji coba skala besar, para ahli materi sependapat bahwa model pembelajaran permainan modifikasi permainan tradisional yang terdiri dari 5 modifikasi permainan, yaitu: (a) permainan Selodor, (b) permainan bola kasti, (c) permainan Engklek/ Jemprak, (d) permainan Lompat Kubur, dan (e) permainan Kucing-Tikus, yang dikembangkan termasuk dalam kategori baik dan efektif.

Berdasarkan hasil observasi dari ahli materi terdapat pelaksanaan uji coba skala besar model pembelajaran modifikasi permainan tradisional materi menggap bahwa model yang dimodifikasi sudah baik dan efektif, sehingga 
tidak ada lagi masukan atau tidak diperlukan revisi.

Analisis data uji coba pelaku di lapangan menunjukkan bahwa dari hasil data observasi untuk guru pelaku uji coba di lapangan menunjukkan bahwa dalam menerapkan modelmodel permainan yang sudah di rancang pelaku uji coba terlihat efektif dalam pemakian terhadap peserta didik.

Analisis data kuesioner siswa menunjukkan bahwa hasil data kuesioner untuk siswa menujukkan bahwa respon dari peserta didik yang menjadi sampel pada uji coba skala besar, secara umum memberikan respon yang positif terhadap model pembelajaran dengan modifikasi permainan tradisional terdapat $(2,5 \%)$ yang menyatakan mengalami kelelahan dalam mengikuti pembelajaran dengan model yang dimodifikasi, hal ini dikenakan kondisi tingkat kebugaran siswa yang tidak sama serta karakteristik siswa sekolah dasar masih berada pada usia tumbuh kembang.

\section{Revisi Produk Setelah Uji Coba Skala Kecil}

Berdasarkan analisis data observasi dan masukan dari ahli materi pada uji coba skala kecil, maka dilakukan revisi terhadap produk yang dikembangkan. Revisi produk yang dilakukan hanya pada beberapa bagian saja, karena para pakar/ahli materi menggap bahwa model pembelajaran modifikasi permainan tradisional yang dikembangkan sudah baik dan efektif, namun masih perlu dilakukan revisi terhadap pro- duk. Revisi produk setelah uji coba skala kecil yang dilakukan yaitu: (a) Pada model permainan selodor dilakukan revisi terhadap jarak garis gobak sodor dan penambahan lapangan gobak sodor sehingga peserta didik semuanya ikut bergerak saat bermain tanpa ada cadangan. (b) Pada model pembelajaran modifikasi permainan tradisional bola kasti, pengkondisian/ pengelolaan siswa yang lebih baik. (c) Pada permainan model lompat kubur dilakukan pelaksanaan pembelajaran dengan posisi peserta didik bersilang tanpa berpasangan, serta semua peserta didik disarankan menggunakan sepatu.

\section{Validasi Ahli Materi}

Uji coba di lapangan terhadap model permainan dapat dilaksanakan setelah mendapat validasi dari para pakar dan guru SD (ahli materi) oleh karena itu, diajukan revisi draf awal model permainan untuk mendapatkan validasi. Sebelum melakukan validasi, ahli materi menilai revisi draf awal model permainan dengan menggunakan instrumen skala penilaian sebagai bahan panduan dalam menilai permainan. Terdapat 13 butir klarifikasi dalam skala nilai untuk pembelajaran motorik, ahli dalam pembelajaran pendidikan jasmani dan guru Penjaskes sekolah dasar SD.

Data hasil penilain para pakar/ahli materi terdapat draf awal model pembelajaran motorik dalam permainan tardisional, dipaparkan pada tabel 5 dan 6 berikut ini.

Tabel 5. Penilaian Skala Nilai oleh Pakar 1 (Bidang Ahli Pembelajaran Motorik)

\begin{tabular}{|c|c|c|c|c|c|c|c|c|c|c|c|c|c|c|c|}
\hline \multirow{2}{*}{$\begin{array}{c}\text { Model } \\
\text { Permainan }\end{array}$} & \multicolumn{13}{|c|}{ Butir Klarifikasi } & \multirow{2}{*}{\begin{tabular}{|c|}
$\begin{array}{c}\text { Total } \\
\text { Nilai }\end{array}$ \\
13
\end{tabular}} & \multirow{2}{*}{$\begin{array}{c}\text { Presentasi } \\
100\end{array}$} \\
\hline & 1 & 2 & 3 & 4 & 5 & 6 & 7 & 8 & 9 & 10 & 11 & 12 & 13 & & \\
\hline 1 & 1 & 1 & 1 & 1 & 1 & 1 & 1 & 1 & 1 & 1 & 1 & 1 & 1 & 13 & 100 \\
\hline 2 & 1 & 1 & 1 & 1 & 1 & 1 & 1 & 1 & 1 & 1 & 1 & 1 & 1 & 13 & 100 \\
\hline 3 & 1 & 1 & 1 & 1 & 1 & 1 & 1 & 1 & 1 & 1 & 1 & 1 & 1 & 13 & 100 \\
\hline 4 & 1 & 1 & 1 & 1 & 1 & 1 & 1 & 1 & 1 & 1 & 1 & 1 & 1 & 13 & 100 \\
\hline 5 & 1 & 1 & 1 & 1 & 1 & 1 & 1 & 1 & 1 & 1 & 1 & 1 & 1 & 13 & 100 \\
\hline
\end{tabular}

Keterangan: Total nilai 13, dengan persentase $100 \%$ dapat dikatakan bahwa model pembelajaran ini Layak untuk diuji coba. Apabila total nilai $<13$, dan kurang dari $70 \%$ maka dapat dikatakan bahwa model pembelajaran ini belum layak untuk diuji coba.

Berdasarkan penilain pakar/ahli motorik satu Prof. Dr. Sukadiyanto M. Pd terhadap draf awal model pembelajaran motorik dengan pendekatan bermain menggunakan permainan tradisional, terlihat bahwa total nilai dari masing-masing model telah memenuhi persyaratan kelayakan untuk diujicobakan di lapangan. Pakar/ahli satu juga telah memberikan validasi terhadap draf awal model pembelajaran motorik dengan pendekatan permainan tradisional untuk diuji coba di lapangan. 
Tabel 6. Penilaian Skala Nilai oleh Pakar 2 (Bidang Ahli Pembelajaran Pendidikan Jasmani)

\begin{tabular}{|c|c|c|c|c|c|c|c|c|c|c|c|c|c|c|c|}
\hline \multirow{2}{*}{$\begin{array}{c}\text { Model } \\
\text { Permainan }\end{array}$} & \multicolumn{13}{|c|}{ Butir Klarifikasi } & \multirow{2}{*}{\begin{tabular}{|c|}
$\begin{array}{c}\text { Total } \\
\text { Nilai }\end{array}$ \\
13 \\
\end{tabular}} & \multirow{2}{*}{$\begin{array}{c}\text { Presentasi } \\
100 \\
\end{array}$} \\
\hline & 1 & 2 & 3 & 4 & 5 & 6 & 7 & 8 & 9 & 10 & 11 & 12 & 13 & & \\
\hline 1 & 1 & 1 & 1 & 1 & 1 & 1 & 1 & 1 & 1 & 1 & 1 & 1 & 1 & 13 & 100 \\
\hline 2 & 1 & 1 & 1 & 1 & 1 & 1 & 1 & 1 & 1 & 1 & 1 & 1 & 1 & 13 & 100 \\
\hline 3 & 1 & 1 & 1 & 1 & 1 & 1 & 1 & 1 & 1 & 1 & 1 & 1 & 1 & 13 & 100 \\
\hline 4 & 1 & 1 & 1 & 1 & 1 & 1 & 1 & 1 & 1 & 1 & 1 & 1 & 1 & 13 & 100 \\
\hline 5 & 1 & 1 & 1 & 1 & 1 & 1 & 1 & 1 & 1 & 1 & 1 & 1 & 1 & 13 & 100 \\
\hline
\end{tabular}

Keterangan: Total nilai 13, dengan persentase $100 \%$ dapat dikatakan bahwa model pembelajaran ini layak untuk diuji coba. Apabila total nilai $<13$, dan kurang dari $70 \%$, maka dapat dikatakan bahwa model pembelajaran ini belum layak untuk diuji coba

Berdasarkan penilain ahli dua Prof. Dr. Suharjana M. Kes terhadap draf awal model pembelajaran motorik dengan model permainan tradisional, terlihat bahwa total nilai dari masing-masing model permainan telah memenuhi persyaratan kelayakan untuk diujicobakan di la- pangan. Pakar/ahli materi dua juga telah memberikan validasi terhadap draf awal model pembelajaran motorik dengan pendekatan bermain menggunakan permainan tradisional untuk diuji cobakan di lapangan.

Tabel 7. Penilaian Skala Nilai oleh Pakar 3 (Bidang Ahli Guru Pendidikan Jasmani SD)

\begin{tabular}{|c|c|c|c|c|c|c|c|c|c|c|c|c|c|c|c|}
\hline \multirow{2}{*}{$\begin{array}{c}\text { Model } \\
\text { Permainan }\end{array}$} & \multicolumn{13}{|c|}{ Butir Klarifikasi } & \multirow{2}{*}{$\begin{array}{c}\begin{array}{c}\text { Total } \\
\text { Nilai }\end{array} \\
13 \\
\end{array}$} & \multirow{2}{*}{$\begin{array}{c}\text { Presentasi } \\
100\end{array}$} \\
\hline & 1 & 2 & 3 & 4 & 5 & 6 & 7 & 8 & 9 & 10 & 11 & 12 & 13 & & \\
\hline 1 & 1 & 1 & 1 & 1 & 1 & 1 & 1 & 1 & 1 & 1 & 1 & 1 & 1 & 13 & 100 \\
\hline 2 & 1 & 1 & 1 & 1 & 1 & 1 & 1 & 1 & 1 & 1 & 1 & 1 & 1 & 13 & 100 \\
\hline 3 & 1 & 1 & 1 & 1 & 1 & 1 & 1 & 1 & 1 & 1 & 1 & 1 & 1 & 13 & 100 \\
\hline 4 & 1 & 1 & 1 & 1 & 1 & 1 & 1 & 1 & 1 & 1 & 1 & 1 & 1 & 13 & 100 \\
\hline 5 & 1 & 1 & 1 & 1 & 1 & 1 & 1 & 1 & 1 & 1 & 1 & 1 & 1 & 13 & 100 \\
\hline
\end{tabular}

Keterangan: Total nilai 13, dengan persentase 100\% dapat dikatakan bahwa model pembelajaran ini Layak untuk diuji coba. Apabila total nilai $<13$, dan kurang dari $70 \%$, maka dapat dikatakan bahwa model pembelajaran ini belum layak untuk diuji coba.

Berdasarkan penilain guru Penjaskes Kusrinah, S.Pd. Jas terhadap draf awal model pembelajaran motorik dengan model permainan tradisional, terlihat bahwa total nilai dari masing-masing model permainan telah memenuhi persyaratan kelayakan untuk diujicobakan di lapangan. Pakar/ahli materi guru Penjas SD telah memberikan validasi terhadap draf awal model pembelajaran motorik dengan pendekatan bermain menggunakan permainan tradisional untuk diujicobakan di lapangan.

\section{Revisi Produk Uji Coba Skala Besar}

Berdasarkan analisis data dari para ahli materi, revisi produk setelah uji coba skala besar tidak perlu dilakukan, karena para ahli menganggap bahwa model pembelajaran modifikasi permainan tradisional yang terdiri dari 5 macam permainan yaitu: (a) permainan Gobak Sodor, (b) permainan Bola Kasti, (c) permainan Engklek/Jemprak, (d) permainan Lompat $\mathrm{Ku}$ bur, dan (e) permainan Kucing-Tikus, yang disusun dalam bentuk buku panduan dan layak untuk digunakan.

\section{Kajian Produk Akhir}

Setelah mendapatkan penilaian dan masukan, baik dari ahli materi maupun guru pendidikan jasmani sekolah dasar pelaku uji coba kemudian dilakukan proses-proses revisi terhadap draf model pembelajaran yang dikembangkan. Akhirnya dihasilkan sebuah model modifikasi permainan tradisional untuk anak sekolah dasar kelas atas, yang terdiri dari lima permainan (masing-masing meliputi beberapa bentuk modifikasi), yaitu: (a) permainan Gobak Sodor, (b) permainan Bola Kasti, (c) permainan Engklek/Jemprak, (d) permainan Lompat Kubur, dan (e) permainan Kucing-Tikus, yang disusun dalam buku panduan dan layak untuk digunakan.

\section{Simpulan dan Saran}

Simpulan

Sebagaimana tujuan penelitian yaitu untuk menghasilkan model pembelajaran dengan pendekatan permainan modifikasi perma- 
inan tradisional untuk anak sekolah dasar kelas atas yang layak digunakan, maka dilakukan pengamatan pengembangan dengan 7 langkah, terdiri dari: (1) pengumpulan informasi di lapangan, (2) melakukan analisis terhadap informasi yang telah dikumpulkan, (3) mengembangkan produk awal (draf awal model), (4) validasi ahli dan revisi, (5) uji coba skala kecil dan revisi, (6) uji coba skala besar dan revisi, dan (7) pembuatan produk final.

Dari hasil analisis data penilain para ahli materi, pelaku uji coba dan kuesioner siswa terhadap model pembelajaran motorik dengan pendekatan permainan modifikasi permainan tradisional yang dikembangkan dapat disimpulkan bahwa: (1) model pembelajaran motorik pendekatan modifikasi permainan tradisional untuk anak sekolah dasar kelas atas ini dinilai baik dan efektif, (2) respon peserta didik yang menjadi sampel dalam penelitian ini, memberikan respon yang positif terhadap model modifikasi permainan tradisional. Oleh karena itu, dapat disimpulkan bahwa model pembelajaran motorik dengan modifikasi permainan tradisional dinilai dapat mengembangkan dan meningkatkan motorik kasar bagi anak sekolah dasar kelas atas.

Produk penelitian dari pengembangan ini berupa model pembelajaran modifikasi permainan tradisional untuk anak sekolah dasar kelas atas yang berisikan lima permainan yaitu: (a) permainan Gobak Sodor, (b) permainan Bola Kasti, (c) permainan Engklek/Jemprak, (d) permainan Lompat Kubur, dan (e) permainan Kucing-Tikus, yang disusun dalam bentuk buku panduan.

Saran Pemanfaatan, Diseminasi, dan Pengembangan Produk Lebih Lanjut

\section{Saran Pemanfaatan}

Model pembelajaran motorik dengan bermain menggunakan modifikasi permainan tradisional untuk sekolah dasar kelas atas sebagai produk yang dihasilkan dalam penelitian pengembangan ini merupakan sebuah alternatif model pembelajaran motorik yang dapat digunakan oleh guru pendidikan jasmani di SD untuk memberikan solusi yang lebih baik bagi terlaksananya pembelajaran motorik di sekolah melalui berbagai aktivitas permainan yang menyenangkan guna memperkaya pengalaman dan meningkatkan kemampuan gerak anak, sehingga membentuk generasi muda yang berprestasi, berkualitas dan berkarakter.

\section{Diseminasi}

Desiminasi hasil penelitian pengembangan dilakukan melalui seminar-seminar, pembuatan artikel, sosialisasi model pembelajaran motorik yang dikembangkan melalui forum KKG guru pendidikan jasmani SD, atau dapat juga dilakukan melalui penelitian tindakan kelas maupun penelitian eksperimen dengan melibatkan guru Penjas SD untuk mengetahui pengaruh dari penerapan model pembelajaran motorik dengan bermain tradisional untuk anak sekolah dasar kelas atas.

\section{Pengembangan Produk Lebih Lanjut}

Selain berupa buku panduan model pembelajaran motorik, produk penelitian dapat dibuat dalam bentuk CD pembelajaran motorik, di samping itu, perlu dilakukan penelitian yang melibatkan subjek coba lebih besar dan cakupan tempat uji coba lapangan yang lebih luas. Di sisi lain dapat juga dilakukan penelitian pengembangan serupa dengan sasaran subjek siswa sekolah dasar kelas atas.

\section{Daftar Pustaka}

Ardiwinata, A, A. dkk. (2006). Kumpulan permainan rakyat olahraga tradisional. Tangerang: Cerdas Jaya.

Arlina. (2008). Pengertian dan sejarah kebudayaan. (http://www.arlinah@petra.ac.id). Diakses 11 November 2012.

Mutohir, T. C dan Gusril. (2004). Perkembangan motorik pada masa anak-anak. Jakarta: Proyek Pengembangan dan Keserasian Kebijakan Olahraga, Dirjen Olahraga, Depdiknas.

Nugroho, Setyo. (2005). Peran kinestesis dalam pembelajaran motorik. Yogyakarta: FIK UNY.

Rahyubi. (2012). Teori-teori belajar dan aplikasi pembelajaran motorik deskripsi dan tinjauan kritis. Bandung: Nusa Media.

Rusman. (2011). Model-model pembelajaran: mengembangkan profesionalsime guru. Jakarta: Rajawali Pers. 
Sudijono, Anas. (2011). Pengantar statistik pendidikan. Jakarta: PT Raja Grafindo Persada.

Sudjana, N. (2005). Penilaian hasil proses belajar mengajar. Remaja Rosdakarya.

Sugiyono. (2011). Metode Penilaian pendidikan (pendekatan kuantitatif, kualitatif dan R/D). Bandung: Alfabeta.

Sujiono, Bambang. (2007). Metode pengembangan fisik (edisi revisi). Jakarta: Universitas Terbuka.
Sukadiyanto. (2001). Pengantar teori dan metedologi melatih fisik. Yogyakarta: FIK UNY.

Sukadiyanto, \& Muluk, Dangsina. (2001). Pengantar teori dan metedologi melatih fisik. Bandung: CV. Lubuk Agung.

Wena, Made. (2009). Strategi pembelajaran inovatif kontemporer. Jakarta: Bumi. 